\title{
On the Referee System as a Barrier to Global Anthropology
}

\section{Gordon Mathews}

In the present paper, I first discuss the lack of a truly global anthropology in the world today and consider why such a world anthropology does not exist. I then offer a more personal account, based on my experience as an editor of an international journal attempting, to some extent, to counter the hegemony of the American anthropological core. Finally, I look at the referee system and argue that, for all its benefits, it nonetheless serves to prevent the emergence of a global anthropology. The major questions raised in this paper are how, in an anthropological world riven by a huge gap between the core and periphery, as well as by different national schools of anthropology, can refereeing of journal articles take place in a fair and balanced way; and, if it cannot take place, what does this mean about the nature and future of anthropology as a discipline?

Keywords: American Anthropological Core; Global Anthropology; National Anthropologies; Referee System

\section{Why There Isn't a Global Anthropology}

A number of anthropologists today have argued, in various ways, that in order for anthropology to reach its potential as a discipline it must become more globalised (see Yamashita, Bosco, \& Eades 2004; Restrepo \& Escobar 2005; Ribeiro 2006; Ribeiro \& Escobar 2006; Yamashita 2006; Boŝković 2008; Kuwayama 1997, 2004; Mathews 2006, 2008). This view is that we need debates from all segments of the world of anthropology in a more or less common anthropological arena in order for the discipline to develop into one that truly spans the globe in its endeavours. This is an ideal that many of us would agree upon, but it does not often happen. Why?

The most fundamental reason it does not happen is that anthropology is not a unified discipline in the same way as disciplines such as medicine and to some extent) economics are but, rather, is set into its different national moulds that often

Correspondence to: Dr Gordon Mathews, The Chinese University of Hong Kong, Anthropology, Shatin, NT, Hong Kong, Hong Kong, Hong Kong. Email: cmgordon@cuhk.edu.hk 
do not communicate much. Anthropology today is essentially divided into a core and periphery, with the core being Anglo-American, particularly American, and the periphery being societies such as Japan, Brazil and Australia. These societies are peripheral not economically, but in the sense that their anthropology has only limited impact upon the core. The extreme periphery consists of societies in Latin America, Africa, the Middle East and South and south-east Asia, whose anthropologies are largely unknown to the core. ${ }^{1}$ The core, in effect, requires the periphery to use the voice of the core if it is to be noticed by the core; the various countries of the periphery typically follow their own different national and regional directions, often paying obeisance to the core in theory, but otherwise ignoring it. Thus, global anthropology — an anthropology where, for example, Brazilian, Japanese, Nigerian and Indian anthropologists discuss and argue with one another, as well as with English and American anthropologists, over a range of anthropological issues - has never gelled, despite a number of efforts to create such an anthropology. ${ }^{2}$

One reason why anthropology does not have a global forum is language. English is, of course, the language of the anthropological core. It would seem to be the optimal language for a global anthropology given current global realities - English is, indeed, the language of global science, with, for example, medical doctors, physicists and engineers from societies across the globe typically reporting on their research in English. However, it is also a language with the historical baggage of colonialism and cultural imperialism, as anthropologists throughout the world are all too aware. Anthropologists in places such as Brazil, Japan and China have their own anthropological traditions in their own languages and may feel no need to communicate much with the anthropological world beyond their own society (Eades 2000, Boŝković \& Eriksen 2008, p. 9), especially if this means that they must communicate in a language that some, at least, resent.

Another reason why anthropology does not take place in a global arena is money. Anthropologists in the developing world may not have access to the publications through which anthropologists communicate and so may be essentially shut out from the anthropological discourse of wealthier societies. This, of course, varies from society to society - anthropologists in East Asia may find it relatively easy to fund their travel to the core to present their views at international meetings if they choose to do so, whereas those from societies in sub-Saharan Africa and South Asia may find this to be utterly impossible (see Nkwi 2006). However, the financial gap is clearly a significant reality. As more and more anthropological writing becomes available on the Internet, this gap may diminish; however, for the most part, this has not yet happened-many scholars in the developing world are shut out of global anthropological conversations simply because they lack the libraries to be able to engage in those conversations.

The lack of a global anthropology is also a matter of another institution, one that is rarely mentioned and that is often seen as salutary but that is, indeed, a problem. I refer to the referee system, the key focus of the present paper. The referee systemwhereby scholars serve as referees in anonymously critiquing an author's work and evaluating that work's suitability for publication or presentation-is valuable in the 
sense that it replaces personal relationships with a relatively objective reading of a given contribution. Anthropologists from East Asia and other areas have often expressed appreciation at how, in Western societies, the referee system does seem to function effectively.

The problem most commonly noted with the referee system is that of personal bias. For example, a scholar submits a paper on a topic on which another scholar has performed extensive research and the latter, as referee, criticises the former for not treating the topic as she herself would have and for not giving her the respect to which she feels she is due; this, perhaps, prevents the paper from being published. This certainly happens, but probably less than is commonly imagined. In my own experience, as author and editor, I would say that this happens with no more than 5 per cent of referees' reports, with most reports being free from such obvious personal bias (although personal preferences for certain viewpoints and styles over others inevitably remains). Rather, the problem sets in when the anonymity of the referee system facilitates not personal, but national, bias.

Anthropologists in different societies have different anthropological perspectives; thus, they may serve, perhaps unwittingly, as national gatekeepers in their capacity as referees for publications, conferences, $\mathrm{PhD}$ theses, tenure or promotion. This is particularly true in terms of the Anglo-American anthropological core. Because so many scholars the world over seek to publish, present or obtain jobs within that core, it wields a remarkable degree of power (even though many scholars in the core seem to be unaware of this power, judging from my conversations with them ${ }^{3}$ ). Anthropological publications in the core-like anthropological publications across the globe - use referees who essentially share their own values and discursive norms, shutting out, to some extent, those who do not share those values and norms.

Let me focus more closely on the American side of this core, because, being American trained, I am more fully aware of this system's workings. Foreign scholars who seek to publish in top American anthropological journals or to present panels at American anthropological meetings are, to some extent, forced to follow American anthropological discursive norms, which, at least unwittingly, may claim to be global norms. Gustavo Lins Ribeiro has described this American core using the term 'metropolitan provincialism' (2006, pp. 377-8), a provincialism that may mask itself as universalism. As Takami Kuwayama has argued:

The world system of anthropology defines the politics involved in the production, dissemination, and consumption of knowledge about other peoples and cultures. Influential scholars in the core countries are in a position to decide what kinds of knowledge should be given authority and merit attention. The peer-review system at prestigious journals reinforces this structure. Thus, knowledge produced in the periphery, however significant and valuable, is destined to be buried locally unless it meets the standards and expectations of the core. (Kuwayama 2004, pp. 9-10)

What Kuwayama is saying is that foreign scholars who seek to be heard in the core are forced to adopt the discursive norms of the core: to be heard by Americans, they must 
sound like Americans in their theorising and writing. No doubt referees from the core do not consciously seek to Americanise the writings they evaluate, but, in effect, this is the role they tend to perform.

The core is more variegated than the statement by Kuwayama above recognises (see Mathews 2008, p. 57): there are many different kinds of anthropological journals published in the core, ranging from those that emphasise the quantitative, to those that emphasise material culture, to those that feature ethnography, to those concerned with cultural criticism and to those that emphasise textual analysis. However, there is indeed a core that consists of, in an American context, publications such as American Ethnologist and Cultural Anthropology, among other journals. My suspicion is that this core has grown more de facto xenophobic over recent decades simply in that native-speaker English - full not just of jargon, but also of native speaker-specific literary stylistics - has become more and more important in these journals.

I date this change to the ascendance of Clifford Geertz in the 1960s and 1970s, who, although a wonderful writer, is extraordinarily difficult for non-native speakers to emulate in their writing. His literary version of anthropology, and the countless successors it has spawned within postmodernism and beyond, has had the effect of making the anthropology of the core less universal and more American. This Americanisation of American anthropology has, in effect, justified the localisation and nationalisation of other anthropologies and thus the pluralisation of anthropology as a discipline. The evidence broadly points to this national differentiation taking place long before American anthropology retreated into itself, but the latter no doubt added to the impetus for the former, which continues all the more strongly today (as I have been told by anthropologists from half a dozen different countries). For example, if one reads American Ethnologist alongside the Japanese Bunka Jinruigaku, the Indian Indian Anthropologist and comparable journals from China, Brazil and Germany, the national differentiation of anthropologies is clear.

If anthropology were closer to the social and natural sciences in its emphasis, then writing within the discipline could follow more of a universal pattern. This may, in turn, enable a genuinely international referee system to be effective, because there would be more common agreement as to what 'good' anthropology consisted of. However, in an anthropological world that has a dominant core essentially rejecting many of those who do not belong to it, as well as distinct national traditions with their own anthropological values and norms, can an international referee system ultimately be effective? Perhaps not. Of course, as alluded to above, there are many factors influencing how referees judge the work they are sent, including their specialities and individual personalities. However, inasmuch as there are different national traditions of anthropology, these too undoubtedly have an impact. If what is thought to be a good anthropology paper is not the same in Japan, India, China, Brazil or Ghana as in the US, then this attests to the importance of national difference and imperils the emergence of any truly global anthropology. 


\section{On Editing a Global Anthropology Journal}

This is where my own experience as an editor of a journal over the past 8 years may be worth discussing. It was partly due to our discontent with the Anglo-American core that my colleague Tan Chee-Beng and I founded the journal Asian Anthropology in 2001, seeking anthropologists writing about Asia from diverse perspectives and backgrounds. ${ }^{4}$ We do not have a particularly large circulation, but we are available in major university libraries throughout the US, Europe and Asia. We have published works by scholars from many backgrounds, including those from the US, Europe, China, Japan, Korea, India, Bangladesh, Thailand, Malaysia, Singapore, Hong Kong and Australia, among others. Our basic assumption has been that, to some extent, there is a common anthropological approach to Asia, making a journal such as Asian Anthropology possible. However, although the journal has been relatively successful, I have experienced significant doubts concerning our ability to judge papers in terms of a common anthropological focus.

My co-editor and I are from different national backgrounds-I am American, based in Hong Kong for the past 15 years, whereas he is Malaysian Chinese and also a long-term Hong Kong resident-but we were educated at the same American graduate programme in anthropology at Cornell University, although in different decades. We are sympathetic to the idea of different national traditions in anthropology, but we do, uncomfortably, often find ourselves acting as gatekeepers. How are we to respond when we receive a paper from Bangladesh that is exclusively focused on Bangladeshi ethnic minority issues with no discussion of their broader relevance to a world beyond Bangladesh, a paper from China that explores an anthropological topic with no discussion of other countries' anthropological writings on similar topics over the past 20 years, a paper from India that seems to reinvent the wheel by exploring anthropological issues that have not been dealt with for decades elsewhere, or a paper from Japan that seems purely empirical, without the theoretical argument that most Western-based anthropologists take for granted as being necessary for a paper? And how can we compare the publishability of these papers with those of Western scholars - Western European and, especially, American - who may show a thorough understanding of American discursive norms but lack the empirical data of many of their Asian counterparts and may display a shaky grasp of the nuances of those data? These are the kinds of issues we face on a regular basis.

The profiles I have just offered fit national anthropological stereotypes, although, for each, there are exceptions: American anthropology papers tend to be focused on theory without very much empirical data or full explications of those data; Japanese anthropology papers tend to focus on empirical data without much theoretical basis, except one fleetingly borrowed from Western totemic figures; and Chinese and Indian papers tend to be focused on problems and issues in their own societies without much global context. These stereotypes have a grain of truth and, in effect, serve as barriers to a global anthropology: we are all doing different things for different audiences. Diversity is wonderful in many contexts: multiple anthropologies are not 
necessarily a bad thing, in that there are distinct national and regional concerns in different anthropologies and anthropology is often at its best when it engages in those concerns. Nonetheless, if we seek to have a global anthropological discussion within a common discursive arena or, more practically, to publish an anthropological journal spanning different national anthropologies, then decisions must be made as to what is 'good' and what is not, what is 'valid' and what is not. If we, as editors, take a position that anthropology is pluralistic, then how can we decide what to print? Authors from a number of different societies seek us to print their papers: on what basis can we decide between them? If, instead, we take a position that anthropology is universal, then whose version of universalism do we opt for? The American core's version of universalism? Or various Asian versions of universalism? Again, how can we decide?

As editors, we have tried to deal with these issues practically. We endeavour, whenever possible, to have referees from different societies - generally one Western or Western-trained referee and one referee from the author's own society. This is often effective in that it can afford us multiple perspectives as to the publishability of a paper. Often these different referees agree; but what should we do when one referee says, 'this is a good paper and should be published' and the other says, 'this is a bad paper and should not be published' - as has happened to us several times over the years? Of course, we, as editors, must make our judgements - we do so sometimes on partly practical grounds (do we need an article for our upcoming issues or are we full?) but, more often, on our own senses of anthropology as a discipline. Can we avoid our own national biases? ${ }^{5}$ Perhaps we can: after all, we were each trained in the US for half a dozen years and have practised anthropology for decades since then in south-east Asia and Hong Kong. Nonetheless, that American training took place in our formative years as anthropologists, shaping us as anthropologists ever thereafter. Like it or not, we are, to some extent, anthropologically American and this cannot help but colour our judgements in an unwitting, and perhaps unconscious, way.

In a practical sense, having referees from different societies certainly helps in overcoming this bias, although, on occasion, we must still judge between them. If we were to have yet another referee adjudicating between our two referees-local and American-based - this could help even more, but the situation rapidly becomes complex to the point of absurdity. If we have an American and a Japanese anthropologist refereeing a Japanese paper and they disagree, should we then choose a Chinese anthropologist as our third referee? Or, given the antipathy between Japan and China, would a Western European anthropologist be better? However, is it possible that a European anthropologist is typically closer to an American anthropological view? What, then, of an Indian anthropologist? One can easily see how ridiculous this game could become. Of course, national biases are only one factor influencing a referee's judgements - time and again, we have seen that we cannot predict a given referee's judgements solely on the basis of where they are located and what their training has been ${ }^{6}$ - but although this factor cannot be wholly accounted for, it also cannot be ignored and it often does matter. 
Another practical issue that we, as editors, have dealt with concerns those papers we receive that are interesting in terms of their topics but that would probably never pass the theoretically inclined strictures of Western referees. To overcome this problem, we have instituted a separate category, apart from articles, called 'Reports', where a piece of well-presented ethnographic data can be published without having to go through the refereeing process. This has enabled a far broader range of papers to be published in Asian Anthropology, sometimes from graduate students or from authors without a professional anthropological background, but even more, from anthropologists from a diverse array of societies that otherwise would not be represented in the journal. This has often meant that we must go through and edit these papers, a process that, in one extreme case, involved extracting ten pages from a 150-page manuscript that my co-editor and I deemed suitable for publication but only with severe winnowing. This enables us to print an array of papers that we may never otherwise have printed, but it also means that my co-editor and I effectively co-opt the role of referees and so the same basic problems recur: how do we judge? Most basically, we choose to print those reports we deem 'interesting', but the category of 'interesting' is, of course, itself problematic.

Underlying this judgement is the question of our relationship with the American core. I have profound misgivings about that core, as I have expressed in various writings (Mathews 2006, 2008), but many of my publications have come from that core. This is also true, albeit to a lesser extent, of my co-editor. In any case, the fundamental issue remains: given our American anthropological training, are we inevitably gatekeepers for that American core? Or can we claim to judge anthropological writings in an objective way, one that transcends our training?

One issue is, of course, that of audience. Every journal must face this question: who are its readers? In our case, some 40 per cent of readers are members of the Hong Kong Anthropological Society, who are likely to be students and teachers of anthropology in Hong Kong, or else laypeople with a keen interest in China and other parts of Asia. However, our other readers, from whom we hear less frequently, are those in mainland China and in libraries worldwide. We must consider those in the New York Public Library and other such institutions who happen to pick up our journal: what will they make of what we publish? This is, of course, not a question for us alone. Every journal and, for that matter, every author of every book or article must consider who the work is directed towards. The answer to this question determines not only what is published, but also the tone that different anthropological works adopt. This consideration of audience particularity is simultaneously a practical necessity and an obstacle to anthropological universality.

The biggest single problem, one that I have been circling around over and over in this paper, is this: what represents, in anthropological writing, a different anthropological tradition that must be respected and what represents quality, good or bad, in an objective sense? Of course quality must be judged - we receive six or seven times more submissions than we can print and there must be some standard against which to judge what we print. However, can we do so without merely reproducing the 
American core? We take great care in choosing referees and in publishing reports, as detailed above, but the problem inevitably remains. My co-editor and I must judge which papers are anthropologically worth publishing and which are not-we have to do this in order to publish a journal. However, is this ultimately legitimate? We muddle through the publishing of a journal, but I, for one, cannot answer this question.

\section{An Anthropological World Without Referees?}

It is difficult to see how the problem I have set forth in the present paper can be solved, given the current structure of anthropological publishing. Reputable anthropological journals and academic publishers as a rule use the referee system. In the absence of universal disciplinary standards, the referee system tends to channel different kinds of anthropological writings into different national and subdisciplinary categories. It would be highly illuminating (if extremely difficult, because these processes tend to be highly confidential and somewhat idiosyncratic) if a study could be done of how exactly noted anthropological journals and publishers across the globe choose their referees. Serving as a referee is an act of generosity towards a journal, if not necessarily towards a publisher, ${ }^{7}$ and journals tend to be wary of being turned down or ignored because timely referee reports are a major mechanism through which publication can take place. I suspect that most journals and publishers choose referees largely on the basis of 'who they know and can trust' - in effect, those whose anthropological values are in accordance with their own broad values.

Our own journal has fit this pattern. We choose our referees on the basis of who we know, who we know to be an authority on a given topic and who we know will probably give us a response in a timely fashion. We occasionally write to people we have never met asking them to referee for us, especially when the topic is one on which we, as editors, know little, as sometimes happens, but the response is typically less likely to be positive than when we ask people we know. So, we unwittingly and inevitably tend towards using the latter. Editors I have spoken to indicate that they largely follow the same policy in selecting their own referees. Certainly editorial boards of journals seem to be based, at least in part, on this principle, as well as on the principle of selecting the most well-known figures that can be found.

If my sense about how referees are generally chosen is correct, then the national and subdisciplinary segmentation of anthropology is assured. This is not, of course, because of any grand conspiracy, but rather because of the structure of the referee system. It would be possible to transform this system, at least in theory. One can imagine a directory of worldwide anthropologists giving their particular areas of interest: this could serve as a worldwide directory of referees, chosen, perhaps, in alphabetical order on a rotating basis. But, for the reasons I give above, this would almost certainly be unworkable. If a significant proportion of these anthropologists did not answer when called upon or did not submit their reports in a timely fashion 
(problems that have troubled us in reaching out to potential referees, especially from societies with which we have no personal link), then failure is guaranteed.

What, then, of abolishing the referee system? This may create a situation whereby any anthropologist could publish anything, at least without professional gatekeepers. ${ }^{8}$ This could not happen as long as print was the dominant medium for the transmission of anthropology simply because more papers seek print than can be printed. However, in an online world, such as that which we are increasingly entering today, no such limitation need exist - anything can be placed online to be read by anyone. This would solve the problem of the referee system in its core-centrism and its national biases, but would also remove a primary basis for anthropology as a discipline today: all gatekeepers would vanish. There are, of course, online journals that are refereed-most open-access Internet publishing in the sciences today is refereed. However, in anthropology, this model may not work for all the reasons we have discussed above (and indeed, several anthropologically related e-journal editors I have spoken to have bemoaned the difficulties they face in finding authors and particularly referees). When a paper is rejected from a print journal, it may never see print unless it passes through the gauntlet of referees at a different journal, by which time it may be out of date. Conversely, a rejected author on the Internet may very easily put his or her paper online and find, perhaps, just as many readers without benefit of journal sponsorship. Let me suggest, in my closing argument in this paper, that this may be the direction towards which anthropology is now moving in fits and starts. And I suggest that this may not be a bad thing.

In open-source publishing, Wikipedia offers a very different source of authority than the Encyclopaedia Britannica and, by some accounts, is as accurate as the Encyclopaedia Britannica (see BBC 2005; Giles 2005). This issue of accuracy will long remain an open question, but it may be that the Internet will lead to a whole new conception of anthropological authority. Perhaps, in future, anthropological authority will come to be made up of numbers of readers alone, because an audience of readers will decide for itself, with no gatekeepers, what is worth reading and because anybody can place whatever they choose on the Web for readers to give credence to as they see fit. Whether this will ultimately lead to a better, more mature anthropology or simply to chaos and the utter loss of all anthropological standards we cannot know at present. In any case, it may be that the issues I am grappling with in this paper will be largely irrelevant 30 or 40 years from now as cyberspace transcends national bounds and the core and peripheries of anthropological knowledge will increasingly cease to exist. Perhaps, in short, the Internet may help destroy anthropological colonialism and nationalism. But will this save anthropology as a discipline or, perhaps, destroy it too?

My dream is of an anthropology that can become a universal discipline, in which anthropologists from across the world can address and debate one another in a common anthropological forum. For this to happen, anthropology cannot simply consist of people from rich societies investigating people from poor societies (or people from wealthy segments of a society investigating the poor in that society), but 
will need to become everybody studying everybody else. Anthropology, as is commonly recognised, has traditionally been White people from rich countries investigating the non-White poor. Today, this picture is obviously outmoded, but we do see a global pattern of studying down. Americans and Japanese anthropologists do their fieldwork in poorer societies globally; Chinese and Indian anthropologists investigate poorer minority people in their own societies. Each different society has its own permutation of this pattern, but globally this pattern by and large holds (with, of course, numerous individual exceptions among anthropologists). For anthropology to reach its global potential, it can no longer be an echo of Lewis Henry Morgan and Edward B. Tylor's hierarchies of 140 years ago. Instead of a one-way traffic of Americans, British and Japanese anthropologists going to Mongolia, Uganda and India, Mongolian, Ugandan and Indian anthropologists should also be going to the US, UK and Japan to study the exotic people there.

I am, of course, far from the first anthropologist to express this dream, but it seems as unrealisable now as it has ever been. All the inequalities of wealth in the world, in its core and peripheries, are mirrored in the world of anthropology. This ideal of a global anthropology will no doubt take generations or centuries to realise. Meanwhile, however, it is at least possible that the eclipse of the referee system will involve the first step towards the eventual emergence of a global anthropology.

\section{Notes}

[1] The anthropological core and periphery resemble the world systems analysis of Wallerstein (2004) and Arrighi (2005), but differ in the sense that, in anthropology, it is not primarily a matter of economics, but rather of global influence. Core and periphery can of course be drawn in a number of ways (see Kuwayama 2004; Mathews 2008) and my particular designations may seem idiosyncratic to some. The key, for the purposes of the present analysis, is not where a particular society's anthropology is placed, but rather that the AngloAmerican core more or less dominates other anthropologies across the globe.

[2] There have certainly been attempts to create such a forum. The International Union of Anthropological and Ethnological Sciences (IUAES) in its conferences, most recently in Kunming in July 2009, marks one such effort. However, not many anthropologists from the core attend these meetings. Most American anthropologists forego them because they are often held far from American shores and, instead, attend their own American Anthropological Association meetings.

[3] In this context, it may be worth discussing the history of this paper. The president of the American Anthropological Association, Setha Low, who is acutely aware of the issues I discuss in this paper, heard an earlier version of the paper delivered in Kunming, China, at the IUAES meeting in July 2009 and urged me to submit a shorter version of it to Anthropology News, distributed to all members of the American Anthropological Association. Thereafter, the paper was summarily rejected by two of its different editors, whereas the nonAmerican Asia-Pacific Journal of Anthropology expressed a keen interest in the paper. The reasons for the rejection may be idiosyncratic-perhaps I simply write bad 700-word columns, although I myself am a column editor for Anthropology News - but may, in a larger sense, be due to the fact that these editors feel that the bulk of American anthropological readers aren't interested in the issues I discuss here. 


\section{G. Mathews}

[4] Tan Chee Beng stepped down as editor in 2009, and Sidney Cheung took his place. Because at the time of writing I have yet to publish an issue with Sidney Cheung, I leave this discussion as is.

[5] This question refers, by implication, not simply to refereeing articles, but also to evaluating students. If anthropology is not a global discipline but is, at least to some extent, divided into national camps, then can a professor from one national background properly evaluate a student from another? This doubt seems less relevant when referring to students starting out, for whom there are more likely to be universal disciplinary standards by which they are judged, but may be quite relevant when referring to the evaluation of $\mathrm{PhD}$ dissertations.

[6] This is of course a complicated matter. What of an anthropologist who has spent her first 50 years in India and then obtained employment in the US? What of an anthropologist who, after undergraduate training in Japan and graduate school in the US, makes her professional life in China or in Australia? In an age of globalisation, national anthropological background, although an important consideration, is also increasingly blurry as a criterion, at least for some anthropologists. My own sense is that where an anthropologist went to graduate school remains the most important criterion for ascertaining their 'anthropological nationality'.

[7] Referees for anthropological journals are rarely rewarded, but referees of book manuscripts for academic publishers often receive monetary payments or the chance to choose free books from that publisher in return for their efforts.

[8] In the book publishing world, there may be popular gatekeepers as well as professional gatekeepers. In Japan, for example, as well as some European societies, many anthropologists publish books with popular publishers that provide no academic referees, but strictly examine manuscripts in their quest for maximum book sales.

\section{References}

Arrighi, G. (2005) 'Globalization in world systems perspective', in Critical Globalization Studies, eds R. Appelbaum \& W. Robinson, Routledge, London, pp. 32-54.

BBC. (2005) Wikipedia Survives Research Test, 15 Dec. Available at: http://news.bbc.co.uk/2/hi/ technology/4530930.stm, accessed 16 October 2009.

Boŝković, A. (ed.) (2008) Other People's Anthropologies: Ethnographic Practice on the Margins, Berghahn, New York.

Boŝković, A. \& Eriksen, T. (2008) 'Introduction: Other people's anthropologies', in Other People's Anthropologies: Ethnographic Practice on the Margins, ed. A. Boŝković, Berghahn, New York, pp. 1-19.

Eades, J. S. (2000) “"Why don't they write in English?" Academic modes of production and academic discourses in Japan and the West', Ritsumeikan Journal of Asia Pacific Studies, vol. 6, pp. 58-77.

Giles, J. (2005) 'Internet encyclopaedias go head to head', Nature, vol. 438, pp. 900-1. Available at: http://www.nature.com/nature/journal/v438/n7070/full/438900a.html, accessed 16 October 2009.

Kuwayama, T. (1997) 'Genchi no jinruigakusha-naigai no Nihon kenkȳu o chūshin ni' [Native anthropologists: With special reference to Japanese studies inside and outside Japan], Minzokugaku kenkyu, vol. 61, issue 4, pp. 517-42.

Kuwayama, T. (2004) Native Anthropology: The Japanese Challenge to Western Academic Hegemony, Trans Pacific Press, Melbourne.

Mathews, G. (2006) 'If anthropology is a science, then the East-West dichotomy is irrelevant: Moving towards a global anthropology', in Dismantling the East-West Dichotomy: Essays in Honour of Jan van Bremen, eds J. Hendry \& H. W. Wong, Routledge, London, pp. 183-8.

Mathews, G. (2008) 'Why Japanese anthropology is ignored beyond Japan', Japanese Review of Cultural Anthropology, vol. 9, pp. 53-69. 
Nkwi, P. N. (2006) 'Anthropology in a postcolonial Africa: The survival debate', in World Anthropologies: Disciplinary Transformations Within Systems of Power, eds G. L. Ribeiro \& A. Escobar, Berg, Oxford, pp. 157-78.

Restrepo, E. \& Escobar, A. (2005) '“Other anthropologies and anthropology otherwise”: Steps to a world anthropologies framework', Critique of Anthropology, vol. 25, no. 2, pp. 99-129.

Ribeiro, G. L. (2006) 'World anthropologies: Cosmopolitics for a new global scenario in anthropology', Critique of Anthropology, vol. 26, no. 4, pp. 363-86.

Ribeiro, G. L. \& Escobar, A. (eds) (2006) World Anthropologies: Disciplinary Transformations Within Systems of Power, Berg, Oxford.

Wallerstein, I. (2004) World Systems Analysis: An Introduction, Duke University Press, Durham.

Yamashita, S. (2006) 'Reshaping anthropology: A view from Japan', in World Anthropologies: Disciplinary Transformations Within Systems of Power, eds G. L. Ribeiro \& A. Escobar, Berg, Oxford, pp. 29-48.

Yamashita, S., Bosco, J. \& Eades, J. S. (eds) (2004) The Making of Anthropology in East and Southeast Asia, Berghahn, New York. 